"Social values as determinants of entrepreneurial intentions among university students in Cape Town - South Africa"

\begin{tabular}{|c|c|c|}
\hline AUTHORS & \multicolumn{2}{|l|}{$\begin{array}{l}\text { Vivence Kalitanyi } \\
\text { Dick Jacobus (Kobus) Visser }\end{array}$} \\
\hline ARTICLE INFO & \multicolumn{2}{|c|}{$\begin{array}{l}\text { Vivence Kalitanyi and Dick Jacobus (Kobus) Visser (2016). Social values as } \\
\text { determinants of entrepreneurial intentions among university students in Cape } \\
\text { Town - South Africa. Problems and Perspectives in Management, 14(3-1), 185- } \\
\text { 193. doi:10.21511/ppm.14(3-1).2016.05 }\end{array}$} \\
\hline DOI & \multicolumn{2}{|c|}{ http://dx.doi.org/10.21511/ppm.14(3-1).2016.05 } \\
\hline RELEASED ON & \multicolumn{2}{|l|}{ Tuesday, 06 September 2016} \\
\hline JOURNAL & \multicolumn{2}{|c|}{ "Problems and Perspectives in Management" } \\
\hline FOUNDER & \multicolumn{2}{|c|}{ LLC "Consulting Publishing Company "Business Perspectives" } \\
\hline \multirow{2}{*}{ NUMBER OF REFERENCES } & & 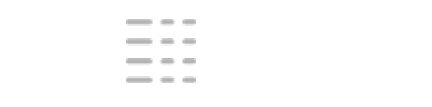 \\
\hline & NUMBER OF FIGURES & NUMBER OF TABLES \\
\hline 0 & 0 & 0 \\
\hline
\end{tabular}

(C) The author(s) 2022. This publication is an open access article. 
Vivence Kalitanyi (South Africa), Dick Jacobus (Kobus) Visser (South Africa)

\title{
Social values as determinants of entrepreneurial intentions among university students in Cape Town - South Africa
}

\begin{abstract}
An empirical study was conducted in Cape Town - South Africa - to determine whether social values (family, parents' work and education) have an impact on entrepreneurship students in the universities of Cape Town, University of Stellenbosch, and University of the Western Cape, as well as Cape Peninsula University of Technology. The paper reviewed the literature about the role social values plays in the people's lives. Respondents were the entrepreneurship university students. Data were collected in classrooms, and, in most cases, with the facilitation of both the lecturer and the researcher. Bivariate and multivariate tests of statistical significance were conducted, while Cronbach's Alpha was used to measure the reliability of the research tool. Findings suggest that social values of the university students have an impact on their entrepreneurial intentions. The paper ends with recommendations to universities, entrepreneurship lecturers, parents, government and businesses, as well as civil society organizations.
\end{abstract}

Keywords: social values, entrepreneurship intentions, university students, Cape Town.

JEL Classification: Y4.

\section{Introduction}

Social aspects (family, work, education) have been largely recognized as crucial in shaping entrepreneurial decisions (Kinyua, 2013, p. 334) and the current study strove to determine their sphere of influence in the South African environment. Léon, Descals and Dominguez (2007, p. 73) agree with the above statement, as they asserted that research on individual differences between entrepreneurs and nonentrepreneurs, to determine the characteristics of a typical entrepreneurial personality, has not achieved sufficiently sound results. The results of research have rather been subjected to an enormous amount of criticism, both methodological and theoretical, and this has shown the inadequacy of personality traits for predicting entrepreneurial behavior.

Similarly, Léon et al. (2007, p. 73) affirmed that coming from a family with links to business or with its own firm, gradually familiarizes a person with the world of commerce - research has shown that $30 \%$ of the parents of entrepreneurs are small businessmen/women or self-employed people, compared to $19 \%$ in the case of parents of non-entrepreneurs.

On the gender variable, a number of cross-continent studies have indicated that, in general, the ratio of men to women entrepreneurs is 1.8 to 1 , so that practically twice as many men are involved in entrepreneurial activity as women (Castro, Pistrui, Coduras, Cohen \& Justo, 2002). Through the section on respondents' characteristics, the current study also showed the level of women's interest in participation in entrepreneurial education arising from family backgrounds. As far as

(C) Vivence Kalitanyi, Dick Jacobus (Kobus) Visser, 2016.

Vivence Kalitanyi, Ph.D., Professor, Dean of Economic and Management Sciences Faculty, University of the Western Cape, School of Business and Finance, Cape Town, South Africa.

Dick Jacobus (Kobus) Visser, Ph.D., Professor, University of the Western Cape, School of Business and Finance, Cape Town, South Africa. work experience is concerned, Lazer (2005) shows the role of work experience on entrepreneurship behavior by positing that individuals with diverse work experiences will find entrepreneurial opportunities more attractive.

With regard to education, Kirby (2004) recognizes that in order to develop entrepreneurs, considerable changes have to occur especially in the process of learning and teaching entrepreneurship, as well as its content. He further suggests that there needs to shift from educating "about" entrepreneurship to educating "for" entrepreneurship. While Gibb (2004a) supported this opinion, Léon et al. (2007, p. 74) asserted that education can stimulate the development of entrepreneurial behavior in different ways, such as an increase of knowledge about the setting-up and management of the businesses, as well as the promotion of personal attributes associated with the entrepreneurs. These can be motivators to achieve an internal locus of control or self-efficacy.

Another aspect of social variables is social support. This refers to the candidates' expectations and beliefs about the support they will get from the groups to which they belong (parents, siblings and spouse) and from other reference groups (friends, colleagues and teachers) in the process of setting up a business or being self-employed. This aspect has been recognized as important in the explanation of a person's behavior about venture creation, mainly after Ajzen's (1991) theory of Planned Behavior which explains choice of professional career.

In light with this emerging body of knowledge about the role of social values in instilling entrepreneurial intentions, the current study aims at investigating the extent to which entrepreneurship students in Cape Town universities are influenced by their social values to behave entrepreneurially. 


\section{Literature review: contextualizing the study}

1.1. Entrepreneurial intentions. Pihie (2009) defined intentionality as a behavioral intention resulting from attitudes and becomes an immediate determinant of behavior. Choo and Wong (2009) further posited that intention is the single best predictor of entrepreneurial behavior, while Vesalainen and Pihkala (2000) defined intentionality as a conscious state of mind that leads attention (and therefore experience and action) toward a specific object (goal) or pathway to achieve it. Hence, according to them, individuals who start a business not only have a propensity to start, but also, in addition, adopt a rational behavior to attain their goals. Malle and Nelson (2003) define intentions as the configuration of mental states (intention, belief, desire) that confers intentionality upon a behavior.

Well before, Bird (1988), had defined intentionality as a conscious state of mind that leads attention (and therefore experience and action) toward a specific object (goal) or pathway to achieve it. Hence, according to them, individuals who start a business not only have a propensity to start, but also, in addition adopt a rational behavior to attain their goals. Intentionality is, thus, grounded on cognitive psychology that attempts to explain or predict human behavior.

In the view of Henley (2005, p. 3), psychological evidence claims that intentions are a crucial predictor of subsequent planned behavior and that entrepreneurial intention is an important phenomenon, one that has attracted substantial cognitive research. Intentions of behavior can be strong indicators of that behavior (Fishbein \& Ajzen, 1975). Furthermore, Bird (1988) posited that the role of entrepreneurial intention is especially manifest in the beginning of the organization, since the influence of other external stakeholders, corporate structure, politics, image and culture, is not yet established. Consequently, the founder's intention determines the form and the direction of a nascent organization at its inception.

While previous authors referred to entrepreneurial intentions as the best predictor of individual behaviors and particularly when these behavior are not common, Delmar and Davidsson (2000) supported this argument that entrepreneurial ideas start with inspiration, though intentions are needed in order for them to become manifest.

Van Gelderen, Brand, Van Praag, Bodewes, and Van Gils (2008) stated that entrepreneurial intentions play a central role in understanding the entrepreneurship process, because they form the underpinnings of new organizations and, because entrepreneurship occurs over time, entrepreneurial intentions might be viewed as the first and pivotal stage in an evolving, long-term process. Entrepreneurial intentions not only have an effect on the intended or newly established organization, but also influence the actions of existing organizations. As a result, existing organizations embody and elaborate intentions that ultimately affect a venture's success. An illustrative example would be Chief Executive Officers' (CEOs') entrepreneurial intentions directly affecting the organization that they lead.

In support of the above statement, Wiklund (1999) showed that CEOs' intentions to create a new value within existing organizations, which is accomplished through the values of innovative, proactive, and risky actions, have an impact on venture growth. Following a similar approach, Wiklund and Shepherd (2003) empirically demonstrated that the intention to be innovative and proactive while taking risks enhances a firm's performance.

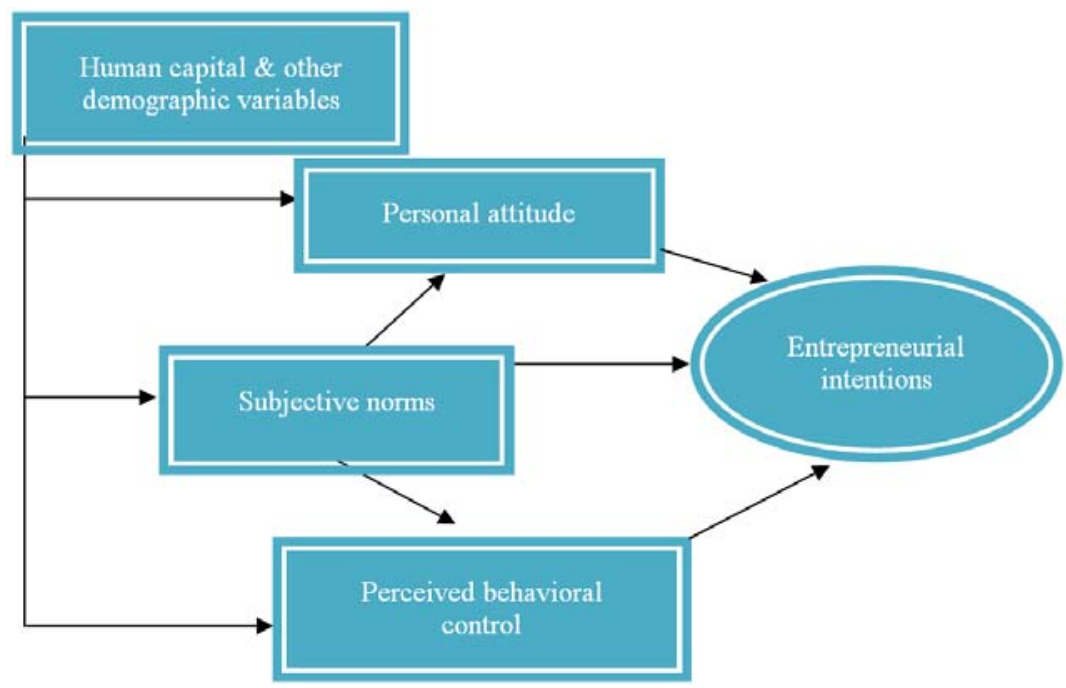

Fig. 1. Entrepreneurial intention model 
The Figure 1 above shows the role of society in shaping entrepreneurial intentions. Human capital, personal attitude and subjective norms are all life variables that are nurtured from the community we live in, and together with what is perceived to be the measurement of the success in a particular behavior, intentions to behave entrepreneurially can be created.

In his study, Fatoki (2010, p. 91) found a low level of entrepreneurial intentions among graduates in South Africa. The results reveal that most graduates prefer to work for private companies or public organizations rather than venturing into entrepreneurship.

Fatoki's results correlate with Kazela's findings in 2009 that the general motivation among disadvantaged communities is to earn an academic qualification which will make them more suitably qualified for the employment market. They find this preferable to considering self-employment. This is the same reason for the low Total Early-Stage Entrepreneurial Activity (TEA) rate in South Africa as that pointed out by Herrington, Kew and Kew (2009). In Fatoki's (2010, p. 92) opinion, the low level of entrepreneurial intentions in South Africa results from a number of obstacles that include the lack of capital - the macro-economy.

A study by Scheepers, Solomon and De Vries (2009, p. 59) on entrepreneurial intentions and behavior of South African university students investigated the sector which students would prefer to venture into, their relative innovativeness of their concept, their current experience, as well as the steps they go through to turn their intentions into reality.

1.2. Social values. Fatoki (2010, p. 89) posited that family background can be a motivator for entrepreneurial intentions, while Rodermund (2004) suggest that entrepreneurial intention is influenced by family history in such a way individuals who come from entrepreneurial parents tend to become, or to develop entrepreneurial behavior and intention. In the same vein, Samuelsson and Kaga (2008) observed that sustainable development must begin in early childhood, as the values, attitudes, behaviors and skills acquired in this period may have a long-lasting impact in later life.

Dehart, Sroufe and Cooper (cited in Mbebeb, 2009) pointed out that concerning learning work transition, entrepreneurial competence is one of the major changes in life course development, especially in early childhood, as children broaden their world through experience with siblings, peers, teachers and parents. There is a significant body of knowledge on socializing the developing child by the African family, but this knowledge is mainly focused on vocational development, particularly entrepreneurship priming (Mbebeb, 2009, p. 25).
Luiz and Mariotti (2011, p. 49) used race, gender and family history to examine the influence of these on entrepreneurial behavior.

Mbebeb (2009, p. 23) argued that entrepreneurial mind-set priming is a viable component of early childhood education through life skills orientation within the family. He further stated that historically, vocational training of children has been the responsibility of the family and this even before the child is exposed to the school world, a source of mismatch between acquired skills and sustainable livelihood.

African indigenous education is part and parcel of the culture and it is built on the daily routines and activities of the family and kinsmen, which validates the position of the family as a socializing agent in early childhood education that can promote entrepreneurial competence (Nsaminang, 2007).

Training children to be independent with entrepreneurial skills will promote high need achievement if training is provided by parents (McClelland, 1961a, p. 92). The African family is recognized for the production and consumption of the Early Childhood Care and Education (ECCE) knowledge, as a fundamental institution; it is, therefore, a challenge for academic institutions to consider the role of the family in vocational development in early childhood (Adeyemi \& Adeyinka cited in Mbebeb, 2009).

Smith-Hunter, Kapp and Yonker (2003, p. 9) argued that family and community are other factors that influence entrepreneurial behavior. They posited that Ajzen's Theory of Planned Behavior (1991) considers perceived social norms as a crucial factor in entrepreneurial activity, while family and important social contacts, including network members, establish these norms.

\section{Methods (the way the study was carried out)}

2.1. Design. The study adopted a hypotheticodeductive method, which consists of formulating a testable hypothesis in a form that could be falsified by a test on the observable data. The next step was to specify the most adequate operations to be performed in order to test the specific hypothesis under given conditions, which allows to accept or reject the hypothesis. The study was conducted in the following five phases:

- review of the literature concerning entrepreneurial intentions and role of social values;

- questionnaire drafting and pilot-testing;

- data collection from entrepreneurship students;

- data capturing and generation of statistical data;

- analysis and interpretation of the data. 
A survey-correlational study was found to be the most appropriate method for this study, since it has been frequently used in many researches in the same field. Neuman (2005, p. 250) argued that a survey is often called correlational, while Babbie and Mouton (2001) posits that a survey usually adopts both qualitative and quantitative methodologies. A survey correlational study focuses on selecting a sample of individuals from a population and, then, analyzes the information using statistical techniques to make inferences about the population.

2.2. The population and sample. The number of entrepreneurship students from the four mentioned universities looks, as follows for the 2014 academic year.

Table 1. Determination of the population

\begin{tabular}{|c|c|c|c|}
\hline \multirow{2}{*}{ University } & \multicolumn{2}{|c|}{ Number of students and level of study } & \multirow{2}{*}{ Source of info } \\
\hline & Undergraduate & Postgraduate & \\
\hline UCT & 57 & $62 \mathrm{MBA}$ & $\begin{array}{l}\text { Ms Langenhoven and } \mathrm{Dr} \\
\text { Herrington, respectively }\end{array}$ \\
\hline USB & 250 & $40 \mathrm{MBA}$ & $\begin{array}{l}\text { Mr G. Solomon and M. } \\
\text { Wepener, respectively }\end{array}$ \\
\hline UWC & 170 & 52 Honours & $\begin{array}{l}\text { Mr E. Isaacs and M. } \\
\text { Orrie, respectively }\end{array}$ \\
\hline CPUT & \multicolumn{2}{|c|}{335 for both under and postgraduate } & Dr Iwu and N. Arendse \\
\hline Total & \multicolumn{2}{|c|}{966} & \\
\hline
\end{tabular}

Due to time and financial constraints, all 966 students could not be reached for completing the questionnaire, hence, sampling. The Research Advisors (2006, p. 1) hold the view that it is possible to use one of the sample calculation formulae to construct a table that suggests the optimal sample size - given a population size, a specific margin of error, and a desired confidence interval. Appendices 3, 4, 5 and 6 present the results of these calculations and they may be used to determine the appropriate sample size for almost any study.

Formula for sample calculation:

$$
\begin{aligned}
& N=\left(X^{2 *} N^{*} P *(1-P)\right) \div\left(M E^{2 *}(N-1)\right)+ \\
& +\left(X^{2 *} P^{*}(1-P)\right),
\end{aligned}
$$

where $n=$ sample size; $\mathrm{X}^{2}=$ Chi-Square for the specified confidence level at one degree of freedom; $\mathrm{N}=$ population size; $\mathrm{P}=$ population proportion $(.50$ in the table above); $\mathrm{ME}=$ desired margin of error (expressed as proportion) (The Research Advisors (2006, p. 3) and Krejcie and Morgan (1970).

The Research Advisers (2006) provided a table displaying the population sizes, confidence levels, or margins of error (see Appendix 6). An illustrative example is that if you have 2000 customers and you want to sample a sufficient number to generate a $95 \%$ confidence interval and a 2, 5\% margin error, you would need responses from a sample of 869 of all your customers.

Thus, for the purpose of the current study, the four universities that were the units of investigation had a total of \pm 966 entrepreneurship students and students doing programs involving entrepreneurship modules; and with a $95 \%$ confidence level considered, together with a margin error of $5 \%$, a sample of between 260 and 278 was considered sufficient.

Table 2. Population and sample

\begin{tabular}{|l|l|}
\hline University & Number of students* \\
\hline UCT & $119^{* *}$ \\
\hline US & 290 \\
\hline UWC & 222 \\
\hline CPUT & 335 \\
\hline Total & 966 \\
\hline Sample & 270 \\
\hline${ }^{*} 2014$ academic year figures. & \\
\hline $\begin{array}{l}\text { **This figure from UCT only involves undergraduate students, plus full-time } \\
\text { MBA students, but excludes modular students. }\end{array}$ \\
\hline
\end{tabular}

\section{Data collection}

In all four universities, data collection was done by requesting the lecturers to accord few minutes at the end of their lecturing periods for the students to complete the questionnaires. In most cases, both lecturers and researcher were present.

3.1. Analysis and interpretation. The collected data were coded by means of the Statistical Program for Social Science (SPSS, version 22). The SPSS was utilized to generate the descriptive statistics, as well as correlation statistics. Then, descriptive statistics were compiled with the help of Univariate Analysis (frequency tables, pie chart and histograms), while correlation was done by using a combination of factor analysis (Bivariate analysis), analysis of variance (ANOVA) and Chi-Square for nominal data (Multivariate analysis).

\section{Findings}

4.1. Personal details. This section presents an analysis of data collected from the respondents of the study, i.e., entrepreneurship students from CPUT, UCT, UWC and US. Sub-headings under this section include: age category, gender, race, religion, residential area (whether it is urban, metro or rural) and study level. 


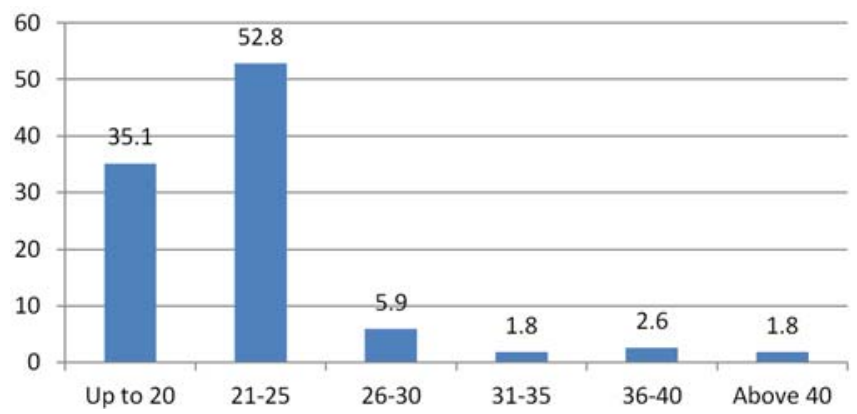

Fig. 2. Age group of respondents (bar chart)

As displayed in Figure 6.1, the majority of the student respondents fell under the age category of $21-25(52.8 \%)$, followed by the category of up to 20 (35.1\%). Both groups represented an overwhelming majority of $87.9 \%$ of the respondents. This finding is justified by the fact that the student respondents were both undergraduate and postgraduate, and all postgraduate students such as those who took their studies on a part-time basis, or those who failed some subjects, were also deemed to be above 20 years of age. Furthermore, the average age of starting university studies in South Africa is 18 , and, since the study involved few Master's students, it is, therefore, understandable that most of the undergraduate students were under 25 years of age.

Interestingly in South Africa, government is creating agencies and institutions to support entrepreneurship. Hence, it is also encouraging to see a good number of young people responding to this call, by undertaking entrepreneurship programs in a country that is in such need of boosting the entrepreneurial spirit among its citizens. Furthermore, Co and Mitchell (2006, p. 349) suggested that HLIs can help to create a more entrepreneurial disposition among young people by:

- instilling a clear understanding of risks and rewards;

- teaching opportunity seeking and recognition skills;

- creating and destroying enterprises;

- developing entrepreneurial traits in students - this finding is in line with this study.

Providing access to entrepreneurship education is especially important in fuelling the pipeline of aspiring entrepreneurs, because of the strong role education plays in raising their levels of self-efficacy, and ultimately their interest in starting their own venture (Wilson, Kickul and Marlino, 2007, p. 14).

Table 3. Gender of respondents

\begin{tabular}{|l|l|c|c|c|c|}
\hline \multicolumn{2}{|c|}{} & Frequency & $\%$ & Valid \% & Cumulative \% \\
\hline \multirow{4}{*}{ Valid } & Male & 116 & 42.3 & 42.6 & 42.6 \\
\cline { 2 - 6 } & Female & 156 & 56.9 & 57.4 & 100.0 \\
\cline { 2 - 6 } & Total & 272 & 99.3 & 100.0 & \\
\hline Missing & System & 2 & 0.7 & & \\
\hline \multicolumn{1}{|l|}{ Total } & 274 & 100.0 & & \\
\hline
\end{tabular}

As reflected in Table 3, a significant percentage of 56.9 of the respondents were female while 42.3 percent were male. Two of the respondents $(0.7 \%)$ did not indicate their gender. The first justification of this finding is that in South Africa, as in many other parts of the world, the number of females outdoes that of their male counterparts. It is, therefore, not surprising to find this gender imbalance in South African institutions of higher learning. At the same time, this finding responds to the calls of government and other stakeholders, such as organizations for human rights and organizations for women empowerment and emancipation, to enrol a larger number of females at universities.

With such a finding about a higher number of women undertaking entrepreneurship studies, there is hope that the future of women entrepreneurs in South Africa looks even brighter.

Table 4. Racial group of respondents

\begin{tabular}{|c|c|c|c|c|c|}
\hline & & Frequency & $\%$ & Valid \% & Cumulative $\%$ \\
\hline \multirow{7}{*}{ Valid } & African & 127 & 46.4 & 46.9 & 46.9 \\
\hline & Chinese & 1 & 0.4 & 0.4 & 47.2 \\
\hline & Coloured & 44 & 16.1 & 16.2 & 63.5 \\
\hline & Indian & 4 & 1.5 & 1.5 & 64.9 \\
\hline & White & 94 & 34.3 & 34.7 & 99.6 \\
\hline & Other & 1 & 0.4 & 0.4 & 100.0 \\
\hline & Total & 271 & 98.9 & 100.0 & \\
\hline Missing & System & 3 & 1.1 & & \\
\hline \multicolumn{2}{|l|}{ Total } & 274 & 100.0 & & \\
\hline
\end{tabular}

Almost half of them (46.4\%) belonged to the African racial group while the White racial group came in second position with $34.3 \%$. Coloureds were represented at $16.1 \%$ while Indian participants comprised $1.5 \%$. The group designated as "other" scored $0.4 \%$ ( 1 respondent) and the same score applied to the Chinese group. This finding, though it does not represent the demographic characteristics of the South African society, reflects the real situation that Blacks (Africans) are the majority (79.2\%), followed by both Whites and Coloureds amounting to $8.9 \%$ each, Indians/Asians at $2.5 \%$ while the group designated as "other" comprised 0.5\% (Statistics SA, 2011, p. 17). Given this statistical information, it is, therefore, not surprising that the same trend would be reflected in South African learning institutions of all levels. 
Traditionally, Whites, who represented a percentage of 34.3 in the study, were the dominant racial group in undertaking entrepreneurial activity. Though it is still the case today, it is also encouraging to see other races such as Coloureds represented in entrepreneurial courses beyond their real national statistical figures. On the other hand, the finding that Blacks, who constitute the majority of the country's population, are more interested in entrepreneurship programs indicates that the entrepreneurial spirit is gaining momentum in South Africa.

\subsection{Correlation analysis.}

Table 5. Correlation between parents' work and entrepreneurial intentions

\begin{tabular}{|l|c|c|}
\hline \multicolumn{1}{|c|}{ Item } & $\begin{array}{c}\text { Pearson } \\
\text { correlation }\end{array}$ & $\begin{array}{c}\text { " } p \text { " } \\
\text { value }\end{array}$ \\
\hline $\begin{array}{l}\text { I often observe my parents/guardians performing } \\
\text { their work. }\end{array}$ & 0.237 & 0.000 \\
\hline $\begin{array}{l}\text { I believe in the importance of the role models in my } \\
\text { society. }\end{array}$ & 0.256 & 0.000 \\
\hline I regard my parents/guardians as my role models. & 0.218 & 0.000 \\
\hline
\end{tabular}

The variable of parents'/guardians' work had eight items. After a bivariate test had been conducted, it was observed that only three items reflected in Table 5 above have the required correlation value of above 0.005 and a par value of 0.000 . This suggests that there is a relationship between the independent variable of parents'/guardians' education and entrepreneurial intentions.

This number of items is low, and it may be because respondents consider nurturing the entrepreneurial intentions by environmental factors rather than by what their parents do. This is especially true, because not all children pursue the same career as their parents.

As Stanworth and Curran (1989) stated, consistent relationships have been established between certain personal background variables, on the one hand, and entrepreneurial behavior, on the other hand, and, in most studies conducted, most of the small business owner-managers had a selfemployed parent. For those individuals intending to start a business, most of them have a parent who has also been in business. This personal background actually has a positive effect on entrepreneurial preparedness, entrepreneurial career expectancy, and desirability of founding a firm (Stanworth \& Curran, 1989).
Table 6. Correlation of parents' education and entrepreneurial intentions

\begin{tabular}{|l|c|c|}
\hline \multicolumn{1}{|c|}{ Item } & $\begin{array}{c}\text { Pearson } \\
\text { correlation }\end{array}$ & $\begin{array}{c}\text { "p" } \\
\text { value }\end{array}$ \\
\hline Parents'/guardians' education inspire their children. & 0.172 & 0.005 \\
\hline $\begin{array}{l}\text { My parents/guardians understand the importance of } \\
\text { education. }\end{array}$ & 0.253 & 0.000 \\
\hline $\begin{array}{l}\text { My parents always encourage me to improve my } \\
\text { education. }\end{array}$ & 0.231 & 0.000 \\
\hline My parents'/guardians' education is an inspiration to me. & 0.182 & 0.003 \\
\hline
\end{tabular}

The bivariate test has shown that out of seven items making up the variable of parents'/guardians' education, only four have a required correlation " $p$ " of more than 0.005 and a par value of between 0.000 and 0.005 , as shown in Table 6 above. This means that there is a relationship between the independent variable of parents'/guardians' education and the dependent variable of entrepreneurial intentions.

This finding is relevant and, indeed, confirms the reason why the respondents of the study, who are entrepreneurship students, are undertaking the program. Under the biographical information, it was discovered that the majority of the respondents' fathers had tertiary education, while the majority of respondents' mothers had matric as their highest qualification. There were some respondents whose parents did not have formal education. Therefore, the fact that the number of items that have a positive correlation with the independent variable is only four out seven, may be a result of the fact that some of the respondents had uneducated parents.

When this finding is compared with that of Luiz and Mariotti (2011, p. 58), it shows diverging opinions about the impact of parents' education on entrepreneurial intentions of their children. The authors posited that education, as a component of social values of students, may not hugely influence how their children perceive entrepreneurship. They pointed out that the more educated the parents, the less likely the children are to start their own businesses, thereby implying that the parents are not transmitting the legacy of entrepreneurship to their progeny. However, the researcher disagrees with this statement and proposes that empirical findings from this study can confirm or contradict this statement. The truth is that education does impact on entrepreneurial intentions among South African students.

\subsection{Regression analysis.}

Table 7. Regression between parents' work and entrepreneurial intentions

\begin{tabular}{|c|c|c|c|c|c|c|}
\hline & \multirow{2}{*}{ Model } & \multicolumn{2}{|c|}{ Unstandardized coefficients } & \multirow{2}{*}{$\frac{\text { Standardized coefficients }}{\text { Beta }}$} & \multirow{2}{*}{$t$} & \multirow{2}{*}{ Sig. } \\
\hline & & B & Std. Error & & & \\
\hline \multirow{2}{*}{1} & Constant & 2.906 & .260 & & 11.159 & .000 \\
\hline & I often observe my parents/guardians performing their work. & .113 & .046 & 181 & 2.447 & .015 \\
\hline
\end{tabular}


Table 7 (cont.). Regression between parents' work and entrepreneurial intentions

\begin{tabular}{|c|c|c|c|c|c|c|}
\hline \multicolumn{2}{|r|}{ Model } & \multicolumn{2}{|c|}{ Unstandardized coefficients } & \multirow{2}{*}{$\begin{array}{c}\text { Standardized coefficients } \\
\text { Beta }\end{array}$} & \multirow[b]{2}{*}{$\mathrm{t}$} & \multirow[b]{2}{*}{ Sig. } \\
\hline & & B & $\begin{array}{l}\text { Std. } \\
\text { Error }\end{array}$ & & & \\
\hline \multirow{7}{*}{1} & I believe in the importance of the role models in my society. & .157 & .059 & 211 & 2.673 & .008 \\
\hline & I regard my parents/guardians as my role models. & .000 & .063 & .000 & .002 & .998 \\
\hline & I regard other family members as my role models. & .027 & .050 & .042 & .541 & .589 \\
\hline & I aspire to exercise the same professions as my parents. & -.001 & .042 & -.002 & -.032 & .974 \\
\hline & I regard my parents'/guardians' work as honorific. & -.045 & .042 & -.074 & -1.056 & .292 \\
\hline & I believe that my parents'/guardians' work has made them financially stable. & .027 & .059 & .043 & .464 & .643 \\
\hline & I aspire to achieve the same financial successes as my parents/guardians. & -.042 & .046 & -.086 &. .922 & .357 \\
\hline
\end{tabular}

The regression analysis was conducted between these two variables to determine which items of the independent variable have the most influence on the dependent variable of entrepreneurial intentions. The model summary of this variable shows an Adjusted R-Square of $0.070>0.05$, and a par value of $0.002<0.05$. This means that the model fits the data. From Table 7 above, it is remarkable that the item of observing parents performing their work increases the chances of entrepreneurial intentions among entrepreneurship students with its par value of less than 0.05 .

Another item that increases the chances of entrepreneurial intentions is that of a role model in society. From the regression analysis, this item scored a par value of $0.008<0.05$. This finding correlates with the finding in the previous variable, where the item of role model was also identified as a contributor to the student's self-efficacy.

Concerning these findings, the same justifications as above apply and, generally, they correlate with the real life situation, where many people tend to follow top achievers who they see around them. As these people constitute their benchmark, individuals will easily be able to measure their successes by comparing themselves against those they regard as their role models or mentors.

\subsection{Parents' education and entrepreneurial intentions.}

Table 8. Regression between parents' education and entrepreneurial intentions

\begin{tabular}{|c|c|c|c|c|c|c|}
\hline & \multirow{2}{*}{ Model } & \multicolumn{2}{|c|}{ Unstandardized coefficients } & \multirow{2}{*}{$\begin{array}{c}\text { Standardized coefficients } \\
\text { Beta }\end{array}$} & \multirow{2}{*}{ t } & \multirow{2}{*}{ Sig. } \\
\hline & & B & Std. Error & & & \\
\hline \multirow{8}{*}{1} & Constant & 2.904 & 231 & & 12.560 & .000 \\
\hline & My parents/guardians are educated (post-matric). & -.101 & .043 & -.196 & -2.358 & .019 \\
\hline & Parents'/guardians' education inspires their children. & .067 & .052 & 113 & 1.297 & .196 \\
\hline & My parents/guardians understand the importance of education. & .141 & .094 & .181 & 1.499 & .135 \\
\hline & My parents always encourage me to improve my education. & .029 & .086 & .040 & .342 & .733 \\
\hline & My parents'/guardians' education is an inspiration to me. & .090 & .050 & .161 & 1.801 & .073 \\
\hline & I aspire to have education as my parents/guardians did. & .018 & .045 & .036 & .397 & .692 \\
\hline & My parents'/guardians' success is owed to education. &. .026 & .048 & -.049 & -.544 & .587 \\
\hline
\end{tabular}

The results provided by the regression analysis concerning the parents' education indicate a statistical significance with $p=0.101>0.05$, while the model summary indicates $0.000<0.05$, meaning that the model fits the data. Considering the individual items in the table, it is fascinating to see how parents' understanding of the importance of education is a strong factor which positively correlates with the variable of education. This translates that education as a variable of the study does increase the chances of self-efficacy among entrepreneurship students becoming self-sufficient and confident in their journey to becoming entrepreneurs.
The regression analysis between education and entrepreneurial intentions reveals that the test of model coefficients was significant at $p=0.000<0.05$ and the model summary indicated $0.074>0.05$. This means the model fits the data. Looking at Table 8 above, the output shows that only one item with $p=0.019<0.05$ qualifies to have an impact on entrepreneurship students' entrepreneurial intentions. This means that the independent variable of parents' education slightly increases the chances of entrepreneurial intentions among their children. This finding correlates with Luiz and Mariotti (2011, p. 58) who found in their study on the perception of entrepreneurship in an 
emerging and culturally diverse economy, namely South Africa, that education as a component of social values of students may not hugely influence how their children perceive entrepreneurship. They pointed out that the more educated the parents, the less likely they are to start their own businesses, thereby not transmitting the legacy of entrepreneurship to their progeny.

\section{Conclusion and recommendations}

After the bivariate analysis, it was found that both dependent variables of social factors, i.e., parents' work and parents' education, have a positive correlation with their entrepreneurial intentions because seven items out of 14 revealed that relationship. This positive relationship was further concreted by the regression analysis, during which three items showed a positive relationship.

This positive relationship as a finding of this study, corroborate the findings of Stanworth and Curran (1989), that consistent relationships have been established between certain personal background variables, on the one hand, and entrepreneurial behavior, on the other hand, and that this personal background actually has a positive effect on entrepreneurial preparedness, entrepreneurial career expectancy and desirability of founding a firm.

It is, therefore, recommended that parents engage in constant conversations about entrepreneurship with their children, coach them and work together if parents are entrepreneurs, and this will result in children taking up their parents' advice. It is also recommended that universities focus on social entrepreneurship in their campaign to implant entrepreneurship behavior among the minds of the students. Due to their proximity to the people, civil-society organizations are also encouraged to use the findings of this research to motivate and cultivate the culture of entrepreneurship among their clients.

\section{References}

1. Ajzen, I. (1991). The theory of planned behavior, Organizational Behavior and Human Decision Processes, 50 (2), pp. 179-211.

2. Babbie, E.R. (2001). The practice of social research. 9th edition. Belmont: Wadsworth.

3. Béchard, J.P. \& Toulouse, J.M. (1998). Validation of a didactic model for the analysis of training objectives in entrepreneurship, Journal of Business Venturing, 13 (4), pp. 317-332.

4. Bird, B. (1988). Implementing entrepreneurial ideas: The case of intention, Academy of Management Review, 13 (3), pp. 442-445.

5. Birley, S. \& Westhead, P. (1994). A taxonomy of business start-up: reasons and their impact on firm growth and size, Journal of Business Venturing, 9 (1), pp. 7-31.

6. Castro, J., Pistrui, J., Coduras, A., Cohen, B. \& Justo, R. (2002). Global Entreprneurship Monitor (GEM): Informe ejecutivo España 2001. Madrid: Instituto de Empresa.

7. Crant, M. (1996). The proactive personality scale as a predictor of entrepreneurial intentions, Journal of Small Business Management, 5 (1), pp. 131-142.

8. Choo, S. \& Wong, M. (2009). Entrepreneurial intention: Triggers and barriers to new venture creations in Singapore, Singapore Management Review, 28 (2), pp. 47-64.

9. Co, M.J. \& Mitchell, B. (2006). Entreprneurship education in South Africa: A nationwide survey. Greenwich: University of Greenwich, The Business School.

10. Fatoki, O.O. (2010). Graduate entrepreneurial intention in South Africa: Motivations and obstacles, International Journal of Business and Management, 5 (9), pp. 87-98.

11. Fishbein, M.G. \& Ajzen, I. (1975). Belief, attitude, intention and behavior: An introduction to theory and research. Massachusetts: Addison-Wesley.

12. Gibb, A.A. (2004a). Creating conducive environments for learning and entrepreneurship. Paper presented at the Internationalising Entrepreneurship Education and Training Conference (IntEnt2004), Naples, July.

13. Gorman, G., Hanlon, D. \& King, W. (1997). Some research perspectives on entrepreneurial education, enterprise education and education for small business management: A ten year review, International Small Business Journal, $15(3)$, pp. 56-77.

14. Henley, A. (2005). From entrepreneurial aspiration to business start-up: Evidence from British Longitudinal Data. Swansea: School of Business and Economics.

15. Herrington, M., Kew, J. \& Kew, P. (2009). Global Entrepreneurship Monitor: South African Executive Report. UCT: Graduate School of Business.

16. Kazela, N. (2009). The roadmap of youth entrepreneurship. Available at: http://www.wcf2009.org/program/down/020_S7I043_Rock_Power_N_Kazela.doc+graduate+entreprneurship+risk +barrier+in+South Africa. Accessed on 30 January 2013.

17. Kinyua, J.N. (2013). Challenges faced by grandparents in managing emotional and behavior problems of orphans in the era of HIV/AIDS, International Journal of Arts and Entrepreneurship, 1 (3), pp. 329-339.

18. Kirby, D.A. (2004). Entrepreneurship education: can business schools meet the challenges? Education + Training, $46(8 / 9)$, pp. 510-519. 
19. Lazear, E.P. (2005). Entrepreneurship, Journal of Labour Economics, 23, pp. 649-680.

20. Léon, J.A.M., Descals, F.J.P. \& Dominguez, J.F.M. (2007). The psychology profile of the University entrepreneur. Madrid: Universidad Nacional de Educacion a Distancia (UNED).

21. Luiz, J. \& Mariotti, M. (2011). Entrepreneurship in anemerging and culturally diverse economy. A South African survey of perceptions, South African Journal of Economic and Management Sciences, 14 (1), pp. 47-65.

22. Malle, B.F. \& Nelson, S.E. (2003). Judging mens rea: The tension between folk concepts and legal concepts of intentionality, Journal of Behavioral sciences \& the law, 21, pp. 563-580.

23. Mattews, C.H. \& Moser, S.B. (1995). Family background and gender: Implications for interest in small firm ownership, Entrepreneurship and Regional Development, 7 (4), pp. 365-377.

24. Mazzarol, T., Volery, T., Doss, N. \& Thein, V. (1999). Factors influencing small business start-ups, International Journal of Entrepreneurship Behavior and Research, 5 (2), pp. 48-63.

25. Mbebeb, F.E. (2009). Developing productive life skills in children: Priming entrepreneurial mindsets through socialization in family occupations, International Journal of Early Childhood, 41 (2), pp. 23-34.

26. McClelland, D. (1961a). The achieving society. Princeton, NJ: Van Nostrand Company.

27. Neuman, W.L. (2005). Social research methods, qualitative and quantitative approaches. 4th edition. Boston: Allyn and Bacon.

28. Nsaminang, B.A. (2007). Cultures in early childhood care and education. Education for All Global Monitoring Report no. 2007/ED/EFA/MRT/PI/3. Pretoria: UNESCO.

29. Pihie, Z.A.L. (2009). Entrepreneurship as a career choice: an analysis of entrepreneurial self-efficacy and intentions of university students, European Journal of Social Sciences, 9 (2), pp. 338-349.

30. Rodermund, E.S. (2004). Pathways to successful entrepreneurship: Parenting, personality, early entrepreneurial competence and interest, Journal of Vocational Behavior, 65 (3), pp. 498-518.

31. Samuelsson, I.P. \& Kaga, Y. (2008). Introduction. In Samuleson, I.P. \& Kaga, Y. (eds.), The contribution of early childhood education to a sustainable society, 9-17. Paris: UNESCO.

32. Scheepers, M.J., Solomon, G. \& de Vries, A. (2009). Global University Entrepreneurship Spirit students' survey: South African Report 2008-2009. Entrepreneurial Intentions and Behavior of South African University Students. Stellenbosch: University of Stellenbosch.

33. Smith-Hunter, Kapp, and Yonkers. (2003). A psychological model of entrepreneurial behavior, Journal of the academy of Business and Economics, 2 (2), pp. 180-192.

34. Stanworth, M.J. \& Curran, P. (1989). Management motivation in the smaller business, Consumer research, 15 (1), pp. 325-344.

35. Statistics South Africa. (2011). South Africa's people: Pocket guide to South Africa 2011/2012. Pretoria: Statistics South Africa.

36. Stevenson, H.H. \& Jarillo, J.C. (1986). Preserving entrepreneurship as companies grow, Journal of Business Strategy, 7 (1), pp. 10-23.

37. Vesalainen, J. \& Pihkala, T. (2000). Entrepreneurial identity, intentions and the effect of the push-factor, International Journal of Entrepreneurship, 3 (2), pp. 145-151.

38. Van Gelderen, M., Brand, M., Van Praag, M., Bodewes, W. \& Van Gils, A. (2008). Explaining entrepreneurial intentions by means of the theory of planned behavior, Career Development International, 13 (60), pp. 538-559.

39. Wiklund, J. (1999). The sustainability of the entrepreneurial orientation-performance relationship, Entrepreneurship Theory and Practice, 24 (1), pp. 37-48.

40. Wiklund, J. \& Shepherd, D. (2003). Knowledge-based resources, entrepreneurial orientation, and the performance of small and medium-sized businesses, Strategic Management Journal, 24 (1), pp. 1307-1314.

41. Wilson, F., Kickul, J. \& Marlino, D. (2007). Our entrepreneurial future: Examining the diverse attitudes and motivations of teens across gender and ethnic identity, Journal of Developmental Entrepreneurship, 9 (3), pp. 177-198. 